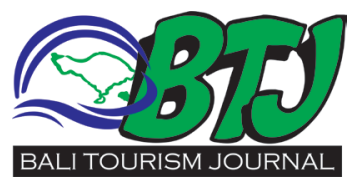

\section{Bali to Ban Backpacker entering The Island. Tourism Minister: It Was Just Misunderstanding!}

I Komang Bayu Segara

*Staff of Dyatmika International School, Bali;

Ik.bayusegara@gmail.com

Received: 2021-05-15

Accepted: 2021-07-20

Published: 2021-08-04

\section{ABSTRACT}

Backpackers are one of the sub-groups detached from mass tourism and seek to achieve a complete tourism experience. ${ }^{1}$ The decline in transportation costs and the growth of communication media via the internet has made backpacking trips continue to increase. Although the trend of backpacker tourism has increased over the years, their image apparently influenced the Indonesian Government's decision, especially when Bali was preparing for tourism opening. During his visit to Bali on Friday, September 10, 2021, Coordinating Minister for Maritime Affairs and Investment Luhut Binsar Pandjaitan mentioned that the authorities would selectively screen foreign tourists who wish to visit Bali, and no backpacker would be allowed. Albeit Jodi Mahardi had clarified Luhut Binsar pandjaitan's statement on September 14, 2021, then reaffirmed many times by the Minister of Tourism and Creative Economic and the Vice Governor of Bali, several foreign media still quoted Luhut's initial statement. The uproar of Prohibiting Backpacker Tourists sounded around the globe and received backlash from expatriates and tourism actors in Bali. Backpacker tourists received a relatively negative image by some economic and tourism actors, but it does not mean that backpacker tourists do not contribute to a region's economy. Some studies suggested that backpacker tourists contribute to small business development and promote tourism destinations to the world.

Keywords: Backpacker, Ban, Bali.

Cite This Article: Segara, I.K.B. 2021. Bali to Ban Backpacker entering The Island. Tourism Minister: It Was Just Misunderstanding!. Bali Tourism Journal 5(2): 32-36. D0l: 10.36675/btj.v5i2.58

\section{BACKGROUND}

Backpackers are one of the sub-groups detached from mass tourism and seek to achieve a complete tourism experience. ${ }^{1}$ The decline in transportation costs and the growth of communication media via the internet has made backpacking trips continue to increase. ${ }^{2} 59$ percent of Backpacker tourists are from Europe. They are from France, Germany, Scotland, England, Sweden, Denmark, Finland, the Netherlands, Slovenia, and other European countries. ${ }^{3}$ Then, nineteen percent from Australia, followed by America (18 percent) and Asia (4 percent). Based on the length of visit in Bali, the average tourist of this type visits Bali for 8-15 days. ${ }^{4}$

Despite the trend of backpacker tourism has increased over the years, their image apparently influenced the Indonesian Government's decision, especially when Bali was preparing for tourism opening. During his visit to Bali, Coordinating Minister for Maritime Affairs and Investment Luhut Binsar Pandjaitan, on Friday, September 10, 2021,

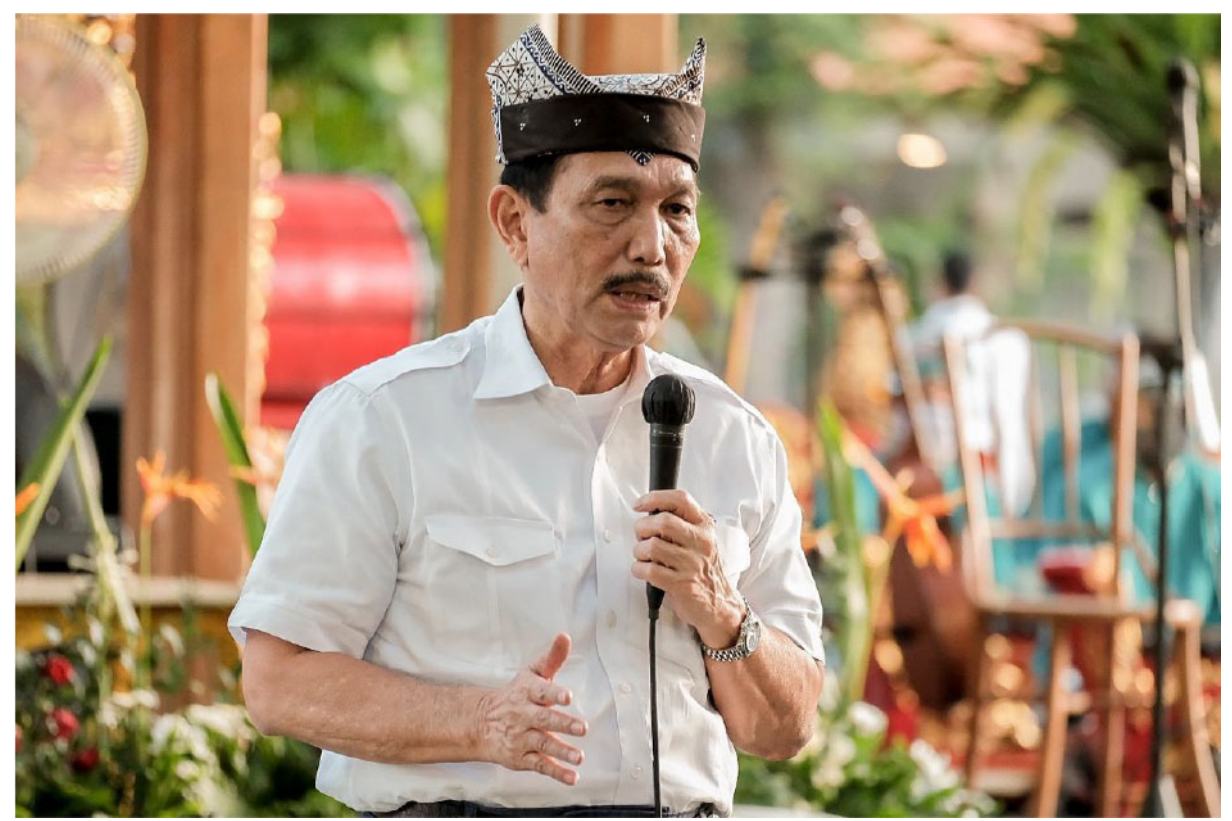

Figure $1 .^{8}$ Coordinating Minister for Maritime Affairs and Investment Luhut Binsar Pandjaitan.

said he would selectively screen foreign tourists who wish to visit Bali. Bali would prefer quality tourists as a priority. "Then, we would filter the tourists who wish to come. We do not want backpackers who come so that Bali is clean; the people who 


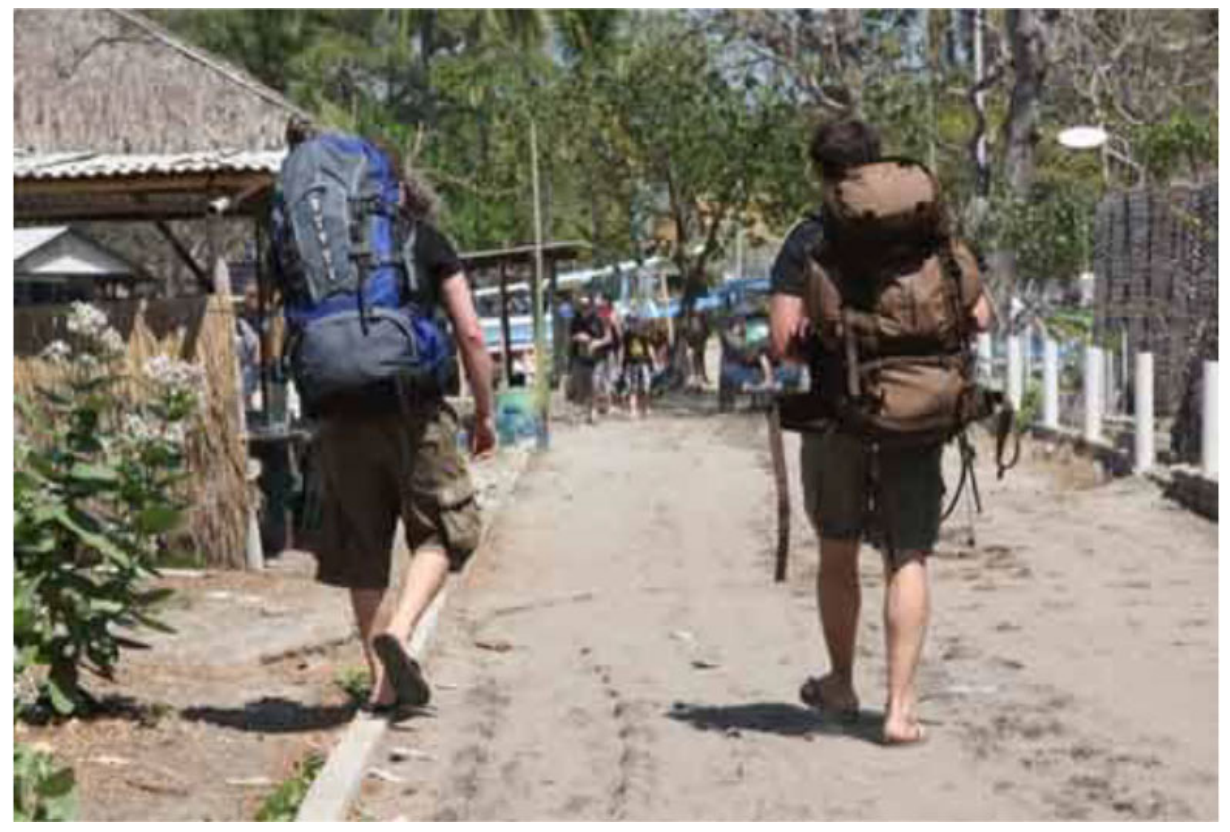

Figure $2 .{ }^{11}$ In 2015, around $40 \%$ of foreign tourists who came to Indonesia made Bali their bucket-list destination. One-third of those travelers are backpackers.

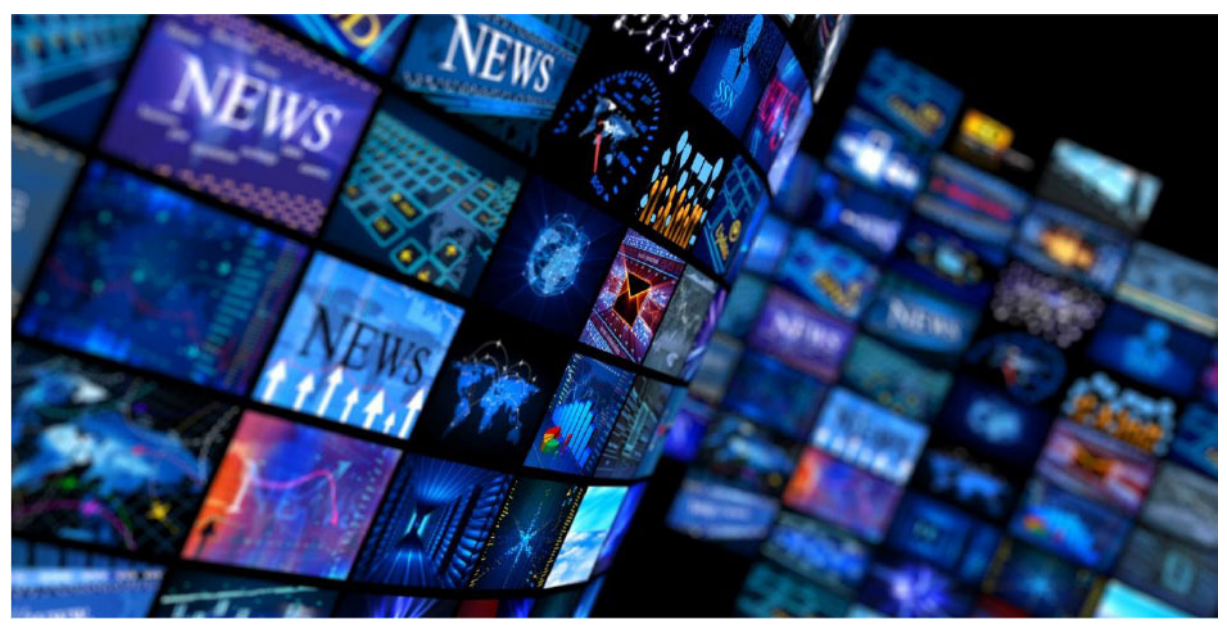

Figure 3. ${ }^{26}$ Albeit Jodi Mahardi clarified Luhut Binsar pandjaitan's statement on September 14, 2021, then reaffirmed many times by the Minister of Tourism and Creative Economic and the Vice Governor of Bali, several foreign media still quoted Luhut's initial statement.

come are qualified," he said. He asked the Balinese people to wait patiently for the opening of international tourism since positive cases of Covid-19 continue to occur albeit recently showed an improving trend. He requested the public to follow the health protocols strictly. Thus, there will be no spiking cases in the future. ${ }^{5}$

According to the study, In Southeast Asia countries, the Government rarely put Backpacker as a potential tourism market, ${ }^{6}$ including Indonesia. The reason was that backpacking is considered as a Grand Tour from lower classes communities. The characteristic of backpacking tourism in carrying a backpack, camping, and live frugally seemed to emphasize the style of low-budget tourism. ${ }^{7}$ Further, Backpackers are often considered not significant to have an impact on the economy.

\section{Image of Backpacker Tourist}

The number of foreign tourists visiting the province of Bali in 2018 recorded as many as
$6,070,473$ million, an increase of 2,068,638 million tourists from 2015. ${ }^{9}$ This increase occurred considering that Bali is a world tourist area. In 2015, around $40 \%$ of foreign tourists who came to Indonesia made Bali their bucket-list destination. One-third of those travelers are backpackers. The factors that encourage backpacker tourists to visit Bali namely cultural/historical, affordable price, variety seeking, tourism facilities, safety and cleanliness, and environment. Its dominant factor was cultural/historical. From data from the Central Statistics Agency, in 2013, 1.5 million tourists stayed at non-star hotels in Bali, increasing around 700 thousand from 2008. Furthermore, data from BPS shows an increase in the number of foreign guests at non-star hotels from year to year, especially in the province of Bali. In 20131.5 million tourists were staying at non-star hotels, an increase of around 700 thousand from 2008.

An increase of Toursist visit also correlated to the increasing number of tourists in morbidity and mortality associated with travel and tourism activities. Backpackers are more at risk of experiencing morbidity and even mortality than tourists who travel with travel agents because backpackers tend to be younger, adventurous, try extreme tours, rent cheap vehicles and drive unsafely. Several studies in the country of origin conducted on tourists who have just returned from traveling in a country show that one-third to one-half of these tourists suffer from diseases, skin infections and show symptoms of certain diseases during and after the trip.

This type of tourist has a higher risk of experiencing health problems compared to other groups of tourists. Because of their young age prefers to travel for a more extended period, with many activities. They tend to migrate to various destinations without being assisted by travel agents. Often, most of them will reduce the cost of accommodation and consumption thus They live in cheap accommodation, which tends to be less safe. Based on the characteristics, foreign backpacker tourists visiting Bali are female tourists aged 20-30 years old, first time traveling to Bali, and traveling alone and using the internet as a source of information. They live in 
cheap accommodation such as hostels, guesthouses, eat/drink at local restaurants and choose motorbikes as transportation. Backpacker staying in Bali $>14$ days with a budget of \pm Rp. 5,000,000. Backpackers who visit Bali like diving tours and the diversity of cultures and traditions that exist in Ubud. ${ }^{12}$

\section{Statement Clarification}

On Tuesday, September 14, 2021, the Coordinating Minister for Maritime Affairs and Investment's spokesman, Jodi Mahardi, clarified Luhut Binsar Pandjaitan's statement during his working visit to Bali. At that time, Luhut mentioned that Government would selectively filter foreign tourists that travel to Indonesia. His statement at some point was allegedly discriminating against backpack travelers. Jodi confirmed that the Government would ensure that all traveler can make their trip to Indonesia without any exception. However, the spokesman said, a ban would certainly be given to those who violated Indonesia's health regulations, laws and immigration rules. "Bali would remain open to all tourists as long as they meet the travel requirements, from abroad to enter Indonesia. Indonesia continually striving to encourage safe, sustainable, and comfortable tourism for tourists," said Jodi. International travelers who wish to visit Bali must show a Covid-19 vaccination certificate, perform three $\mathrm{RT}$ PCR tests, and be quarantined for eight days. ${ }^{13}$

Meanwhile, on Friday, September 17, 2021, the Vice Governor of Bali, Tjokorda Oka Artha Ardhana Sukawati, also known as Cok Ace, emphasized that Bali is a destination for all types of tourists, including the Backpacker. Cok Ace, who was a tourism activist, added that since Bali was required to prepare a gradual opening scheme, it was only natural that the Government decided to limit the number of visits at the outset. $\mathrm{He}$ also said that the foreign tourists allowed to Bali should be from countries where its COVID-19 had been controlled. The traveler must declare that they are in good health and could provide tremendous economic benefits for Bali. ${ }^{14,15}$ Bali itself is reportedly proposing foreign tourism to be opened starting November $2021 .^{16}$

Similar to the statement of the Bali
Vice governor, Minister of Tourism and Creative Economy, Sandiaga Uno, On Monday, September 20, 2021, said his party was preparing Bali to welcome foreign tourists again. The Government was meticulously preparing the opening of Bali to foreigners. He also rephrased the statement of the Coordinating Minister for Maritime Affairs and Investment regarding the reopening of Bali to foreign tourists. Sandiaga explained that the foreign tourists screening when entering Bali did not base on their attributes, such as backpacks. However, it would be focused on the foreign tourists' quality, in terms of attitude and financial ability.

Sandiaga mentioned, "The backpackers referred by Mr. Luhut were those who did not bring dividends. His party confirmed the statement directly to the Coordinating Minister of Maritime Affairs. Tourists who disrespect Local wisdom, break the law, and Covid 19 regulations would not be the target of post-pandemic tourism opening. Indonesia would be open to all foreign tourists who can comply with the regulations, including backpackers, as long as they follow the rules, adhere to health protocols, and respect local wisdom. ${ }^{17,18}$

\section{Response from Other Parties}

Albeit Jodi Mahardi clarified Luhut Binsar pandjaitan's statement on September 14, 2021, then reaffirmed many times by the Minister of Tourism and Creative Economic and the Vice Governor of Bali, several foreign media still quoted Luhut's initial statement. For instance, nzheralds on its news entitled Bali welcomes back tourists as Covid-19 cases fall, backpackers not welcome dated September 15, 2021,19 thetaiger, in its article, entitled Bali eyes wealthy tourists, while considering a ban on backpackers dated September 16, 2021. ${ }^{19}$ Further, ThePrint India's news dated September 20, 2021, citing news from the South China Morning Post, Australian media The Times dated September 21, 2021, Khmertimes and Dmarge dated September 24, 2021, also still reported that Indonesia forbade backpackers to come. $^{20,21,22,23}$

The discourse of Prohibiting Backpacker Tourists itself also received backlash from expatriates and tourism actors in Bali. Michael Chesny, A Canadian expatriate who lived in Seraya, Karangasem, said that screening the tourists class who would visit Bali was considered discriminative and wrong. Backpacker is a traveling style; it does not mean that backpackers are lowclass and unqualified people. The man, who has lived in Karangasem for a long time, also said that backpacker tourists significantly affect small traders. Since their trips, mostly visiting a small village deep inside Bali. ${ }^{24}$ A surfer who first came to Bali in 1975, De Neefe, said hippies and surfers have contributed to reinventing Bali back in the '70s.

Meanwhile, a member of the Bali parliament, I Wayan Kari Subali, preferred that the Government implement rules to protect tourists without limiting them. For example, the tourist who overstays in Bali would be a better option to be monitored. A strong argument came from Azril Azahari, chairman of the Indonesian Tourism Scholars Association. Nevertheless, He argued that backpackers come in large numbers, they do not significantly impact the country's income. He viewed that tourism success should be measured from the number of tourists spending or the length of their stay in Indonesia. ${ }^{25}$

backpacker tourists received a relatively negative image by some circles of economic and tourism actors. However, it does not mean that backpacker tourists do not contribute to a region's economy at all. Backpacker tourists have positively impacted national economic development in countries such as Thailand. It was because backpacker tourists trigger transactions for local commodities that do not need to be imported. Thus, it resulted in a pure economic turnover in a country. ${ }^{27}$ For Indonesia, especially Bali itself, some studies suggested that Indonesia is a destination for backpacker tourists. Bali areas, such as Kuta and Ubud, are favorite destinations visited by these travelers. Kuta is very popular with backpacker tourists. The availability of cheap accommodation and tourist facilities makes Kuta one of the pockets of backpackers in Bali. ${ }^{28}$

In addition, backpacker tourists in the tourist area of Ubud impact the economy, socio-culture, and the environment. The local culinary businesses' growth in the Ubud area and the emergence of tourism businesses in cheap accommodation were 
the actual effects that can be seen up to date. In addition, the emergence of natural attractions such as rafting, tracking, and cycling, provides job opportunities for residents, thereby reducing the potential for urbanization. In the socio-cultural field, tourism activities support cultural preservation efforts through the creativity of dance, painting, and sculpture for tourist consumption. Backpacker tourists are also considered more environmentally friendly than tourists who stay in big hotels. Their interest in economic tourism encourages them to stay in homestays that do not provide hot water for bathing and minimal use of air conditioning. Nevertheless, on the other hand, the high number of tourist arrivals in the tourist area of Ubud also exacerbates congestion due to the unavailability of optimal parking spaces. ${ }^{29}$

\section{CONCLUSION}

The trend of backpacker tourism has increased over the years. However, their image apparently did not captivate the Indonesian Government's decision when Bali was preparing for tourism opening. During his visit to Bali on Friday, September 10, 2021, Coordinating Minister for Maritime Affairs and Investment Luhut Binsar Pandjaitan mentioned that the authorities would selectively screen foreign tourists who wish to visit Bali, and no backpacker would be allowed. Albeit Jodi Mahardi had clarified Luhut Binsar pandjaitan's statement on September 14, 2021, then reaffirmed many times by the Minister of Tourism and Creative Economic and the Vice Governor of Bali, several foreign media still quoted Luhut's initial statement. The uproar of Prohibiting Backpacker Tourists sounded around the globe and received backlash from expatriates and tourism actors in Bali. Backpacker tourists received a relatively negative image by some economic and tourism actors, but it does not mean that backpacker tourists do not contribute to a region's economy. Some studies suggested that backpacker tourists contribute to small business development and promote tourism destinations to the world.

\section{REFERENCES}

1. Currie, Russel R, Tamara Campbell-Trant and Sheilag Seaton. 2011. Joining The In-Crowd: Symbol For Backpacker Identity. International Journal of Culture Tourism and Hospitality Reaserch. 5 (1), pp: 47-56

2. Maritha, Devi Putri. 2010. Profil Pola Pengeluaran Wisatawan Asing Ala "Backpacker" di Yogyakarta. Universitas Sebelas Maret Surakarta.

3. Wallstam, Martin. 2011. Backpacker Institionalization. Thesis. Mittuniversitetet. Mid Sweden University.

4. Menuh NN. Karakteristik Wisatawan Backpacker Dan Dampaknya Terhadap Pariwisata Kuta, Bali. Jurnal Master Pariwisata (JUMPA). 2017.

5. A Fawaidi. Luhut Siapkan Skema Pembukaan Pariwisata bagi Turis Asing di Bali, Larang Backpacker Datang. Kompas[dot]com. 2021. Available at URL: https://regional.kompas.com/ $\mathrm{read} / 2021 / 09 / 10 / 210849978 /$ luhut-siapkanskema-pembukaan-pariwisata-bagi-turisasing-di-bali-larang?page $=$ all

6. Tze Ian, Lee and Musa. 2005. Uncovering International Backpacker to Malaysia. Backpacker Tourism. 2(1), pp: 139-143

7. Gula, Lauren. 2006. Backpacking Tourism: Morally Sound Travel or Neo-Colonial Conquest?. Thesis. International Development Studies, Dalhousie University.

8. Documentation of Kemenparekraf. Bali Buka Pariwisata Internasional, Luhut: Kita Nggak Mau Backpacker yang Datang. Urbanasia. 2021. Available at URL: https://www.urbanasia.com/ bali-buka-pariwisata-internasional-luhut-kitanggak-mau-backpacker-yang-datang-U42175

9. Berita Resmi Statistik Perkembangan Pariwisata Provinsi Bali. No. 77/12/51/Th. XIII, 2 Desember 2019

10. Image from I Nofalia 'Backpacker ke Bali? Siapa Takut! Gini Lho Cara yang Hemat dan Aman'. Finansialku. 2019. Available at URL: https:// www.finansialku.com/backpacker-ke-bali/

11. Manik G, Suwena IK, Suardana IW. Faktor pendorong dan penarik wisatawan backpacker mancanegara berwisata ke Bali. Jurnal IPTA ISSN. 2016;2338:8633.

12. AM Karunia. Soal Larangan Turis Backpacker ke Bali, Jubir Luhut: Yang Dilarang Hanya yang Langgar Aturan. Kompas[dot]com. 2021. Available at URL: https://money.kompas.com/ read/2021/09/14/150216526/soal-laranganturis-backpacker-ke-bali-jubir-luhut-yangdilarang-hanya-yang

13. S Suadnyana. Batasi Kunjungan Saat Buka Pintu Buat Wisman, Bali Tolak Backpacker!. Detik. 2021. Available at URL: https://travel. detik.com/travel-news/d-5728282/batasikunjungan-saat-buka-pintu-buat-wisman-balitolak-backpacker

14. Wagub Bali soal Luhut Larang Backpacker Internasional Datang: Batasi Kunjungan.
Kumparan. 2021. Available at URL: https:// kumparan.com/kumparannews/wagub-balisoal-luhut-larang-backpacker-internasionaldatang-batasi-kunjungan-1wXvGiS8mtx/full

15. I Arri. Backpacker ke Bali Dilarang? Ini Kata Wagub Cok Ace. Inews. 2021. Available at URL: https://bali.inews.id/berita/backpacker-ke-balidilarang-ini-kata-wagub-cok-ace/all.

16. Sandiaga Sebut Wisatawan Asing Backpacker juga Boleh ke Bali, tapi Ada Syaratnya. Tempo. 2021. Available at URL: https://travel.tempo. co/read/1508470/sandiaga-sebut-wisatawanasing-backpacker-juga-boleh-ke-bali-tapi-adasyaratnya

17. K Safitri. Soal Larangan Backpacker ke Bali, Ini Penjelasan Sandiaga Uno. Kompas[dot]com. 2021. Available at URL: https://money.kompas. $\mathrm{com} / \mathrm{read} / 2021 / 09 / 21 / 084000326 / \mathrm{soal}$ larangan-backpacker-ke-bali-ini-penjelasansandiaga-uno-

18. S pollok. Bali welcomes back tourists as Covid-19 cases fall, backpackers not welcome. nzherald[dot]co[nz]. 2021. Available at URL: https://www.nzherald.co.nz/travel/ bali-welcomes-back-tourists-as-covid19-cases-fall-backpackers-not-welcome/ Z7474JNHNFQHOFI6IXKDRIQ3TU/

19. M taylor. Bali eyes wealthy tourists, while considering a ban on backpackers. Thaiger. 2021. Available at URL: https://thethaiger. com/news/regional/indonesia-en/bali-eyeswealthy-tourists-while-considering-a-ban-onbackpackers

20. T Zompa. Covid-19 pandemic: Serious cases rise among unvaccinated in Israel, cases in Sydney fall. theprint[dot]in. 2021. Available at URL: https://theprint.in/world/covid-19-pandemicserious-cases-rise-among-unvaccinated-inisrael-cases-in-sydney-fall/736481/

21. J Booth. Bali Set To Crack Down Hard On Misbehaving Tourists. dmarge. 2021. Available at URL: https://www.dmarge.com/2021/09/ bali-crackdown-misbehaving-tourists.html

22. M Firn. Budget travellers will find a welcome in the Kingdom, insiders insist. khmer times. 2021. Available at URL: https://www.khmertimeskh. com/50942122/budget-travellers-will-find-awelcome-in-the-kingdom-insiders-insist/

23. DS Oktarini. Luhut Batasi Wisatawan Asing di Bali, Turis Backpacker Tak Terima. suarabali[dot]id. 2021. Available at URL: https:// bali.suara.com/read/2021/09/21/111922/ luhut-batasi-wisatawan-asing-di-bali-turisbackpacker-tak-terima

24. AE Purna. Wacana Larang Turis Backpacker akan Rugikan Bali. Bali Express. 2021. Available at URL: https://baliexpress.jawapos.com/ $\mathrm{read} / 2021 / 09 / 20 / 290879 /$ wacana-larang-turisbackpacker-akan-rugikan-bali

25. Hampton MP. Backpacker tourism and economic development: Perspectives from the less developed world. Routledge; 2013 Jul 18. 
26. Image from $\mathrm{K}$ Jha 'Western media biased on India's handling of Covid-19' crisis. SundayGuardianLive. 2020. Available at URL: https://www.sundayguardianlive.com/news/ western-media-biased-indias-handling-covid19-crisis

27. Hampton MP. Backpacker tourism and economic development: Perspectives from the less developed world. Routledge; 2013 Jul 18.
28. Menuh NN. Karakteristik Wisatawan Backpacker Dan Dampaknya Terhadap Pariwisata Kuta, Bali. Jurnal Master Pariwisata (JUMPA). 2017.

29. Sudana IP, Putra D, Nyoman I, Sunarta IN, Dwijendra ST, IPU A. Impact of Backpacker Tourists on the Social, Economic and Environmental Aspects in Ubud, Bali,
Indonesia. Journal of Social and Political Sciences. 2020 Oct 9;3(4).

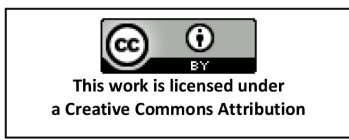

